\title{
MEK Inhibitor RO4987655
}

National Cancer Institute

\section{Source}

National Cancer Institute. MEK Inhibitor R04987655. NCI Thesaurus. Code C82696.

An orally active small molecule, targ eting mitogen-activated protein kinase kinase 1 (MAP2K1 or MEK1), with potential antineoplastic activity. MEK inhibitor RO4987655 binds to and inhibits MEK, which may result in the inhibition of MEK-dependent cell signaling and the inhibition of tumor cell proliferation. MEK, a dual specificity threonine/tyrosine kinase, is a key component of the RAS/RAF/MEK/ERK signaling pathway that regulates cell growth; constitutive activation of this pathway has been implicated in many cancers. 